\title{
Perinatal outcomes of patients diagnosed borderline gestational diabetes mellitus
}

\author{
Gök Özgül', Rauf Melekoğlu², Sevda Yeleç', İpek Eskiyörük', Fatma Tuncay Özgünen' \\ ${ }^{1}$ Department of Gynecology \& Obstetrics, Faculty of Medicine, Çukurova University, Adana, Turkey \\ ${ }^{2}$ Department of Gynecology \& Obstetrics, Faculty of Medicine, Inönii University, Malatya, Turkey
}

\begin{abstract}
Objective: Although the effects of gestational diabetes mellitus to maternal and fetal health are well known, we have few data about maternal and fetal condition of borderline gestational diabetic pregnants who have gestational hyperglycemia not meeting gestational diabetes criteria. Considering this, we aimed to investigate perinatal and neonatal outcomes of patients who have borderline gestational diabetes mellitus in our hospital.

Methods: In this study, we retrospectively examined maternal characteristics, obstetric and perinatal outcomes of pregnants whose antenatal follow-up and birth occurred in Department of Obstetrics and Gynecology in Faculty of Medicine in Çukurova University between January 2009 and January 2013 and who have normal 50$\mathrm{g}$ oral glucose tolerance test (OGTT) but abnormal 100-g OGTT and have normal 50-g OGCT test results. SPSS v. 19.0 statistics software was used for data analysis. For the statistical significance level between results, $\mathrm{p}$ value was taken as $<0.05$.

Results: A total of 239 pregnant women were included in the study. The study group consisted of 105 pregnant women whose $50-\mathrm{g}$ OGTT results were abnormal but 100-g OGTT results were within normal limits and the control group consisted of 134 pregnant women whose 50-g OGTT results were within normal limits. Compared to healthy pregnant women, mean age of the women in the study group was found to be significantly higher $(\mathrm{p}=0.000)$. The duration of hospitalization in the study group was found to be statistically significantly higher compared to the control group $(\mathrm{p}=0.001)$. Mode of delivery, preterm labor, premature rupture of membranes, gestational hypertension, preeclampsia, the presence of fetal distress and postpartum hemorrhage were analyzed in both groups. Only postpartum hemorrhage was found to be statistically significantly higher in the study group compared to the control group $(\mathrm{p}=0.049)$. There was statistically no significant difference in neonates between two groups for LGA, SGA, hypoglycemia, hyperbilirubinemia, neonatal admissions to the intensive care unit and neonatal death.

Conclusion: In our study, perinatal and neonatal outcomes of patients who have borderline gestational diabetes mellitus and normoglisemic condition are same except postpartum hemorrhage and hospitalization period. To acquire perinatal and neonatal outcomes of women with borderline gestational diabetes mellitus, we need further well-designed randomized studies with larger populations.
\end{abstract}

Keywords: Gestational diabetes, glucose tolerance test, pregnancy outcomes.

\section{Özet: Borderline gestasyonel diabetes mellitus saptanan gebelerin perinatal sonuçları}

Amaç: Çalışmanın amacı gestasyonel diyabetin fetal ve maternal sağlığa etkileri oldukça iyi bilinmesine rağmen, gestasyonel diyabet kriterlerini karşılamayan gebelik hiperglisemisine sahip borderline gestasyonel diyabeti olan gebelerin maternal ve fetal durumunu ortaya koyan az sayıda çalışma olmasını göz önünde bulundurarak, hastanemizdeki borderline gestasyonel diyabeti olan hastaların perinatal ve neonatal sonuçlarını irdelemektir.

Yöntem: Bu çalışmada Ocak 2009 ve Ocak 2013 tarihleri arasında Çukurova Üniversitesi Tıp Fakültesi Kadın Hastalıkları ve Doğum Anabilim Dalı Gebe Polikliniğinde antenatal izlemleri yapılan ve doğumları kliniğimizde gerçekleşen gebeler arasından $50 \mathrm{~g}$ OGTT sonuçları yüksek ancak $100 \mathrm{~g}$ OGTT sonuçları normal olan hastalar ile $50 \mathrm{~g}$ OGTT sonuçlari normal olan hastalar tespit edilerek, maternal özellikleri, obstetrik ve perinatal sonuçları retrospektif olarak incelendi. Verilerin analizi için SPSS v 19.0 paket programı kullanıldı. Sonuçlar arasında istatistiksel anlamlılık düzeyi için p değeri $<0.05$ olarak alındı.

Bulgular: Çalışmaya toplamda 239 gebe dahil edildi. 50 g OGTT sonuçları yüksek ancak $100 \mathrm{~g}$ OGTT sonuçları normal sınırlarda olan 105 gebe çalışma grubunu, 50 g OGTT sonuçları normal olan 134 gebe ise kontrol grubunu oluşturdu. Çalışma grubundaki gebelerin yaş ortalamalarının sağlıklı gebelere oranla istatistiksel olarak anlamlı derecede yüksek olduğu saptandı $(\mathrm{p}=0.000)$. Çalışma grubundaki gebelerin hastanede yatış sürelerinin kontrol grubundakilere oranla istatistiksel olarak anlamlı oranda daha fazla olduğu saptandı $(\mathrm{p}=0.001)$. Her iki grubun doğum şekli, erken doğum, erken membran rüptürü, gestasyonel hipertansiyon, preeklampsi varlı̆̆ı, fetal distres varlığı ve postpartum kanama açısından obstetrik sonuçları incelendi. Sadece postpartum kanamanın kontrol grubuna göre çalışma grubunda istatistiksel olarak anlamli derecede fazla olduğu saptandi $(\mathrm{p}=0.049)$. Yenidoğan bebeklerde LGA, SGA, hipoglisemi, hiperbilirubinemi, yenidoğan yoğun bakım ünitesine yatış ve neonatal ölüm görülme oranları arasında da her iki grup arasında istatistiksel olarak anlamlı fark saptanmadı.

Sonuç: Çalışmamızda borderline gestasyonel diyabeti olan hastaların postpartum kanama sıklığı ve hastanede yatış süreleri dışında perinatal ve neonatal sonuçları normoglisemik gebeler ile benzer saptanmıştır.

Anahtar sözcükler: Gestasyonel diyabet, glukoz tolerans testi, gebelik sonuçları.
Correspondence: Rauf Melekoğlu, MD. İnönü Üniversitesi Tıp Fakültesi Kadın Hastalıkları ve Doğum Anabilim Dalı, Malatya, Turkey. e-mail: rmelekoglu@gmail.com Received: November 17, 2014; Accepted: November 30, 2014

Please cite this article as: Özgül G, Melekoğlu R, Yeleç S, Eskiyörük I,

Tuncay Özgünen F. Perinatal outcomes of patients diagnosed borderline gestational diabetes mellitus. Perinatal Journal 2015;23(1):6-12.

(c)2015 Perinatal Medicine Foundation
Available online at: www.perinataljournal.com/20150231002 doi: $10.2399 /$ prn.15.0231002 QR (Quick Response) Code:

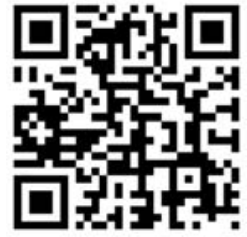




\section{Introduction}

Gestational diabetes mellitus (GDM) is defined as the "carbohydrate intolerance occurring or found for the first time during pregnancy" ${ }^{[1]}$ Pregnancy is characterized by insulin resistance and hyperinsulinemia. This may be predisposing for pregnant women to develop diabetes. This resistance is caused by the influence of some diabetogenic placental secretion hormones (growth hormone, corticotropin releasing hormone, placental lactogenic hormone, progesterone etc). Decreased exercise, increased caloric intake and increased adiposis tissue amount are also among the reasons of insulin resistance. Gestational diabetes is seen in women who have insufficient pancreatic functions and do not have insulin release sufficient enough to tolerate diabetogenic hormone change. ${ }^{[2]}$

It is recommended to all pregnant women to have $50-\mathrm{g}$ oral glucose tolerance test (OGTT) for gestational diabetic screening between 24 and 28 weeks of gestation. ${ }^{[3]}$ If the result is above $140 \mathrm{mg} / \mathrm{dl}$, patient is referred to $100-\mathrm{g}$ OGTT. For GDM diagnosis, at least two threshold values of $100-\mathrm{g}$ OGTT should be met or exceeded. However, there is also a major patient group who has positive result for 50-g OGTT but normal result for 100-g OGTT. Although the effects of gestational diabetes mellitus to maternal and fetal health are well known, maternal and fetal conditions of borderline gestational diabetic women who are between normal glucose values and gestational diabetic levels. Some studies in the literature point out that the pregnant women with normal 100-g OGTT results despite high 50-g OGTT results may have different maternal characteristics compared to normal pregnant women and may have more risks in terms of adverse obstetric outcomes. ${ }^{[4]}$ This group is called as "borderline GDM".

In our study, we aimed to analyze retrospectively the pregnant women with normal 100-g OGTT results despite high 50-g OGTT results and the pregnant women with normal 50-g OGTT results among the cases who were followed up and delivered at the Department of Gynecology \& Obstetrics, Faculty of Medicine, Çukurova University between January 2009 and January 2013, and to investigate and compare their maternal characteristics and obstetric and perinatal outcomes.

\section{Methods}

This study includes 239 pregnant women who had their antenatal follow-ups and deliveries at the
Department of Gynecology \& Obstetrics, Faculty of Medicine, Çukurova University between January 2009 and January 2013 in accordance with the follow-up and delivery protocols prepared in compliance with the Prenatal Care Management Guide and Delivery and Cesarean Labor Management Guide of the Health Ministry, and their babies.

The approval of the Ethics Committee of Faculty of Medicine, Çukurova University was obtained before the study. Also, in compliance with the Helsinki Declaration Principles, all women included in the study were informed in written and verbally about the study and their informed consents were received.

The study group consisted of 105 pregnant women who were at 24-28 weeks of gestation, undergone GDM screening and had normal results for 100-g OGTT despite the high results for 50-g OGTT (those having all values below the threshold value of $100-\mathrm{g}$ OGTT and those with single high value), and the control group consisted of 134 pregnant women who delivered at the same period and had normal results for $50-\mathrm{g}$ glucose screening test performed at 24-28 weeks of gestation.

Pregnant women below 18-year-old and above 35year-old, multipara pregnant women, those with multiple pregnancies, presence of major fetal anomaly in fetus and of maternal chronic diseases (such as chronic hypertension, diabetes mellitus, chronic renal failure asthma, pulmonary or cardiac diseases etc.), patients with maternal thrombophilia history and pregnant women who undergone labor induction were excluded from the study.

In our clinic, we perform 50-g OGTT to pregnant women, who admit to follow-up clinics between 24 and 28 weeks of gestation, by orally administering $50 \mathrm{~g}$ glucose dissolved in $200 \mathrm{ml}$ water. One hour after patient receives glucose solution, venous blood sample is collected from patient and plasma glucose levels are measured spectrophotometrically via oxidase method by using Roche diagnostic kits on Roche/Hitachi (Roche Diagnostics Corp., Indianapolis, IN, USA) device in biochemistry laboratory.

Those with blood glucose levels:

- Below $140 \mathrm{mg} / \mathrm{dl}$ are considered as normal

- Above $200 \mathrm{mg} / \mathrm{dL}$ are considered as directly GDM

- For those with a value between $>140 \mathrm{mg}$ and $<200$ $\mathrm{mg}$, OGTT is carried out with $100 \mathrm{~g}$ glucose after 8-14 of fasting. During this test, venous blood sam- 
ple is collected from patient for fasting blood glucose first and after $100 \mathrm{~g}$ glucose dissolved in 200 $\mathrm{ml}$ is administered to patient, venous blood samples are collected first, second, and third hours, and the samples are analyzed in biochemistry laboratory. GDM diagnosis is established when at least two threshold values used by National Diabetes Data Group are met or exceeded (fasting: 105, first hour: 190, second hour: 165, third hour: 145).

The patients who were included in the study were retrospectively recorded and compared in terms of demographical data such as age, weight, body mass index, smoking habit, gestational age, blood pressure data during the referral for delivery; perinatal data such as preterm labor as a perinatal outcome (delivery before $37+0$ weeks of gestation), pregnancy induced hypertension (hypertension developed without proteinuria after 20 weeks of gestation), presence of preeclampsia (hypertension developed with proteinuria after 20 weeks of gestation), delivery type (vaginal delivery/cesarean), presence of cesarean, shoulder dystocia and postpartum hemorrhage due to fetal distress $(\geq 500 \mathrm{ml}$ blood loss through genital tract after delivery), hospitalization period; and neonatal data such as APGAR score, head circumference, gender, LGA rates according to gestational age [birth weight being $\geq 90 \mathrm{p}$ according to gestational age], SGA rates according to gestational age [birth weight being $\leq 10 \mathrm{p}$ according to gestational age], neonatal hypoglycemia (blood glucose below $40 \mathrm{mg} / \mathrm{dl}$ regardless of birth weight and gestational week), nenonatal hyperbilirubinemia (blood bilirubin levels being at pathological levels according to gestational age, weight and gender), newborn intense care need and neonatal mortality rates of babies born in both groups.

SPSS ver. 19.0 software was used for the statistical analysis of the data. Categorical measurements were summarized as figures and percentages while constant measurements were indicated as mean and standard deviation. The distributions were checked in the comparison of constant measurements among groups; t-test for two independent samples was used for variables displaying parametric distribution while Mann-Whitney U test was used for variables not displaying parametric distribution. Either chi-square test or Fisher's test statistics was used for the comparison of categorical variables such as smoking habit and gender. In all tests, $\mathrm{p}<0.05$ was considered statistically significant.

\section{Results}

A total of 239 pregnant women were included in the study. While mean age of the pregnant women in the study group was $31.5 \pm 5.1$, it was $28.9 \pm 4.4$ in the control group $(\mathrm{p}=0.000)$. It was found that the mean age of pregnant women in the study group was statistically and significantly higher than the mean age of healthy pregnant women. There was statistically no significant difference between the groups in terms of gravida, parity, gestational week, weight, blood pressure, presence of poor obstetric history and smoking habit.

When the groups were evaluated in terms of postnatal hospitalization period, it was seen that hospitalization period of the pregnant women in the study group was $1.7 \pm 0.6$ days while it was $1.5 \pm 0.5$ days in the control group ( $\mathrm{p}=0.001)$. The hospitalization period of the pregnant women in the study group was statistically and significantly higher than those in the control group.

The distribution of the patients in study and control groups by demographic characteristics is shown in the Table 1.

While $54.3 \%$ of the pregnant women in the study group had delivered by cesarean, $45.7 \%$ of them delivered vaginally. While cesarean rate in the control group was $44 \%$, the rate of vaginal delivery was $56 \%$. There was statistically no significant difference between the groups in terms of delivery types $(\mathrm{p}=0.116)$. Preterm labor, premature rupture of membranes, gestational hypertension, presence of preeclampsia and fetal distress, and obstetric outcomes in terms of postpartum

Table 1. Distribution of demographic characteristics according to the groups.

\begin{tabular}{lccc} 
& $\begin{array}{c}\text { Study group } \\
\text { (Mean } \pm \text { SD) }\end{array}$ & $\begin{array}{c}\text { Control group } \\
\text { (Mean } \pm \text { SD) }\end{array}$ & $\mathbf{p}$ \\
\hline Age & $31.5 \pm 5.1$ & $28.9 \pm 4.4$ & 0.000 \\
Weight & $79.6 \pm 11.5$ & $77.6 \pm 10.9$ & 0.180 \\
Gravida & $2.7 \pm 1.2$ & $2.7 \pm 1.4$ & 0.913 \\
Parity & $1.3 \pm 0.6$ & $1.2 \pm 0.8$ & 0.534 \\
Systolic blood pressure & $114.3 \pm 13.6$ & $112.1 \pm 12.2$ & 0.188 \\
Diastolic blood pressure & $71.9 \pm 9.5$ & $70.2 \pm 9.6$ & 0.181 \\
Week of gestation & $38.4 \pm 1.7$ & $38.3 \pm 1.5$ & 0.556 \\
Hospitalization & $1.7 \pm 0.6$ & $1.5 \pm 0.5$ & 0.003 \\
& $\mathbf{n ( \% )}$ & $\mathbf{n}(\%)$ & $\mathbf{p}$ \\
\hline Smoking habit & $4(3.8)$ & $1(0.7)$ & 0.101 \\
Poor obstetric history & $4(3.8)$ & $10(7.5)$ & 0.234 \\
\hline
\end{tabular}


hemorrhage were evaluated. It was found that only postpartum bleeding was statistically and significantly higher in the study group compared to the control group $(\mathrm{p}=0.049)$. The distribution of obstetric outcomes in both groups is shown in the Table 2 .

Newborn follow-up forms of 234 pregnant women included in the study were analyzed and neonatal data were collected. The newborns in both groups were compared in terms of birth weights, head circumference measurements and gender distributions, and statistically no significant difference was found $(\mathrm{p}=0.188$, $\mathrm{p}=0.670, \mathrm{p}=0.958$, respectively).

While the 1-minute APGAR score of $14.2 \%$ of the newborns in the study group was below 7 , it was $12.6 \%$ in the control group. The percentage of those with 5minute APGAR score below 7 was $2 \%$ in the study group while it was $2.9 \%$ in the control group. No statistically significant difference was found between two groups in terms of APGAR scores $(\mathrm{p}=0.815, \mathrm{p}=0.599$, respectively).

No statistically significant difference was seen between the newborns of two groups in terms of LGA, SGA, hypoglycemia, hyperbilirubinemia, hospitalization at newborn intense care unit and neonatal mortality rates. The distribution of neonatal outcomes in both groups is shown in the Table 3.

\section{Discussion}

GDM prevalence increases in the world and it affects $1-14 \%$ of the pregnancies. Estimated GDM prevalence is $1.4-2.8 \%$ in a low-risk population, $3.3-6.1 \%$ in a riskier population, and it may be more than $10 \%$ in high-risk population. ${ }^{[5]}$

There are less data about the gestational hyperglycemia prevalence not meeting the criteria of gestational diabetes mellitus. The data received from the Australian studies showed that $7 \%$ of all pregnant women have hyperglycemia not meeting GDM criteria while $5.5-8.8 \%$ of them already have GDM every year. ${ }^{[6,7]}$ There is no sufficient study in terms of blood glucose follow-ups of this group, how to follow up them and perinatal outcomes. Stamilio et al. confirms that the positivity of $50-\mathrm{g}$ OGTT is an independent risk factor in terms of perinatal complications and indicates that these cases may more frequently benefit from fetal monitorization, nutritional consultation or diabetic diet. ${ }^{[8]}$
Table 2. Distribution of the obstetric outcomes according to the groups.

\begin{tabular}{lccc} 
& $\begin{array}{c}\text { Study group } \\
\mathbf{n}(\%)\end{array}$ & $\begin{array}{c}\text { Control group } \\
\mathbf{n}(\%)\end{array}$ & $\mathbf{p}$ \\
\hline Preterm labor & $4(3.8)$ & $9(6.7)$ & 0.327 \\
Premature rupture of membranes & $13(12.4)$ & $8(6)$ & 0.083 \\
Gestational HT & $5(4.8)$ & $4(3)$ & 0.476 \\
Preeclampsia & $2(1.9)$ & $5(3.7)$ & 0.408 \\
Fetal distress & $4(3.8)$ & $2(1.5)$ & 0.258 \\
Postpartum hemorrhage & $3(2.9)$ & $0(0)$ & 0.049 \\
\hline Delivery type & & & \\
Cesarean & $57(54.3)$ & $59(44)$ & 0.116 \\
Normal delivery & $48(45.7)$ & $75(56)$ & 0.116 \\
\hline
\end{tabular}

According to the results of few studies, many obstetricians define cases, who have positive results for $50-\mathrm{g}$ OGTT but normal results for 100-g OGTT, as glucose intolerant or borderline gestational diabetics and recommend more frequent follow-up. ${ }^{[9]}$ Yee et al. reported advanced maternal age, multiparity and being of Asian or Latin American ethnicity as the risk factors for having abnormal results of glucose tolerance test in the absence of GDM. ${ }^{[10]}$ In our study, we compared the cases in the study group who had high results in $50-\mathrm{g}$ OGTT but normal results in 100-g OGTT with the cases in the control group and found that the age was

Table 3. Distribution of the neonatal outcomes according to the groups

\begin{tabular}{|c|c|c|c|}
\hline & $\begin{array}{l}\text { Study group } \\
\text { (Mean } \pm \text { SD) }\end{array}$ & $\begin{array}{l}\text { Control group } \\
\text { (Mean } \pm \text { SD) }\end{array}$ & $\mathbf{p}$ \\
\hline Birth weight of neonatal & $3224.7 \pm 446.0$ & $3142.7 \pm 498.7$ & 0.188 \\
\hline \multirow[t]{2}{*}{ Head circumference of neonatal } & $34.4 \pm 1.5$ & $34.3 \pm 1.9$ & 0.670 \\
\hline & $n(\%)$ & n (\%) & $\mathbf{p}$ \\
\hline 1-minute APGAR score <7 & $15(14.2)$ & $17(12.6)$ & 0.815 \\
\hline 5-minute APGAR score $>7$ & $3(2)$ & $4(2.9)$ & 0.599 \\
\hline \multicolumn{4}{|l|}{ Gender } \\
\hline Male & $56(53.3)$ & $71(53)$ & 0.958 \\
\hline Female & $49(46.7)$ & $63(47)$ & 0.958 \\
\hline SGA & $2(1.9)$ & $7(5.2)$ & 0.182 \\
\hline LGA & $2(1.9)$ & $5(3.7)$ & 0.408 \\
\hline Neonatal hypoglycemia & $3(2.9)$ & $1(0.7)$ & 0.208 \\
\hline Hyperbilirubinemia & $2(1.9)$ & $1(0.7)$ & 0.427 \\
\hline $\begin{array}{l}\text { Hospitalization at newborn } \\
\text { intense care unit }\end{array}$ & $9(8.6)$ & $16(11.9)$ & 0.400 \\
\hline Neonatal death & $1(1)$ & $1(0.7)$ & 0.259 \\
\hline
\end{tabular}


statistically and significantly high in the study group compared to the control group..$^{9,11-13]}$

Gestational hyperglycemia not meeting the criteria of gestational diabetes mellitus is associated with a series of known health risks. It is known that the insulin resistance which is characteristics for the occurrence of GDM is also associated with the development of preeclampsia. ${ }^{[14]}$ In their multi-central multi-ethnical cohort study (HAPO study), Metzger et al. evaluated 25,505 women in terms of effects of maternal hyperglycemia on gestational outcomes and reported that there was a linear association between preeclampsia prevalence and the results of glucose tolerance test. ${ }^{[6]}$ In our study, we found statistically no significant difference between the study group and the control group in terms of the gestational hypertension and preeclampsia incidence.

Preterm labor is defined as the deliveries occurring before 37 weeks of gestation are completed. GDM and especially pregestational DM are known risk factors for preterm labor. Beigelman et al. found preterm labor rate as $10 \%$ in the study conducted on 3841 pregnant women with GDM. ${ }^{[15]}$ In our study, although preterm labor rate was found at a lower rate in the study group than the control group, there was no statistically significant difference between the groups.

Maternal diabetes is a risk factor for cesarean delivery. Cesarean delivery rate varies from $25 \%$ up to $80 \%$ in diabetic women. Many factors such as diabetic complications including prematurity, macrosomia and nephropathy are associated with high cesarean rates. ${ }^{[16]}$ In their studies, Stamilio et al. observed statistically higher cesarean rate in cases with high results for $5 \mathrm{~g}$ glucose tolerance test but normal results for 100-g OGTT compared to the cases with normal results for 50-g OGTT. ${ }^{[8]}$ Dudhbhai et al. found no significant difference between borderline diabetic pregnant women and the control group in terms of the cesarean rates ${ }^{[13]}$ Hong et al. investigated demographical characteristics and obstetric and neonatal outcomes of patients with borderline gestational diabetes, and found that the cesarean rate due to fetal distress was higher in this group than the normoglycemic pregnant women. ${ }^{[17]}$ In our study, although we found cesarean rates higher in the study group, there was no statistically significant difference between two groups. We also did not see any statistically significant difference between two groups in terms of the cesarean delivery carried out due to fetal distress.

The conditions such as episiotomy extension during vaginal delivery, vaginal laceration and postpartum atonia are observed more frequently in those who deliver large baby. Jastrow et al. reported that the risks for cephalopelvic disproportion, uterine rupture, shoulder dystocia, perineal laceration and postpartum hemorrhage due to LGA or macrosomic baby risk are higher in mothers with maternal hyperglycemia. ${ }^{[18]}$ In our study, the postpartum hemorrhage rate was statistically and significantly higher in the study group than the control group. We found that the most frequent reasons for postpartum hemorrhage seen in the study group were uterine atony followed by delivery tract lacerations and rest placenta induced hemorrhage.

When we compared the groups in terms of maternal hospitalization periods, we found that the mothers in the study group had statistically and significantly longer hospitalization periods than the mothers in the control group. In their study, Hong et al. reported statistically no significant difference between control group and the study group with patients having borderline DM. ${ }^{[17]}$ Long hospitalization periods of the patients in our study group may be due to the high cesarean rates and postpartum hemorrhage rates.

Figueroa et al. indicated in their studies that LGA and macrosomia rates of the patients with borderline gestational diabetes increased 2 and 1.6 times, respectively. ${ }^{[19]}$ In the study of Bonomo et al., the authors suggested that even the slight changes in glucose intolerance may cause overgrowth in babies. ${ }^{[20]}$ From $20 \%$ up to $40 \%$ of diabetic mothers are over 90 th percentile in birth weight according to the gestation. In our study, we found statistically no significant difference between the groups despite the high rates of birth weight in the study group compared to the control group.

Birth traumas, increased preterm labor rates, obstetric conditions such as preeclampsia, and various metabolic disorders depending on the maternal diabetes cause low APGAR scores and high level of intense care needs in babies of diabetic mothers. ${ }^{[2]]}$ Although Hong et al. found statistically no significant difference between 1-minute and 5-minute APGAR scores in patients with high results for 50-g OGTT but normal results for 100-g OGTT, they reported statistically and significantly higher rates for newborn intense care and hospitalization periods in newborns in this group. ${ }^{[17]} \mathrm{We}$, on the other hand, found statistically no significant difference between the groups in terms of 1-minute and 5-minute APGAR scores, newborns' intense care needs and neonatal mortality rates. 
Dodd et al. carried out a study by using the data of 16,975 women who delivered in tertiary healthcare organizations in Australia between 1993 and 2003, and they found that the patients with borderline GDM had risks for preeclampsia and cesarean and when compared to the babies of mothers with normal results for glucose tolerance test, they indicated that the babies of these patients had increased risks for hypoglycemia and hyperbilirubinemia. ${ }^{[7]}$ We did not observe statistically any significant difference between two groups in terms of neonatal hypoglycemia, hyperbilirubinemia, and SGA and LGA baby rates. We believe that the reason is low numbers of patients in the study and control group, and non-availability of detailed neonatal information in the patient files analyzed retrospectively.

\section{Conclusion}

Gestational hyperglycemia not meeting the criteria of gestational diabetes mellitus affects a great number of pregnant women. Hyperglycemia seen during pregnancy is associated with a series of negative gestational outcomes including preeclampsia, delivery trauma and type II DM development in mother, and future obesity, type I and type II DM development in baby. While we do not have certain threshold values to be categorized for establishing GDM diagnosis, the values for upper limit to initiate the treatment in order to keep blood glucose within normal limits in case of gestational hyperglycemia are also unclear. In our study, except postpartum hemorrhage rate and hospitalization periods of the patients with gestational diabetes, the perinatal and neonatal outcomes were similar with the outcomes of normoglycemic pregnant women. While there are researchers recommending to refer patients with gestational hyperglycemia not meeting GDM and type II DM diagnosis criteria to dieticians and to carry out blood glucose monitorization and follow-ups more frequently, there are also researchers who assert that such approaches would increase labor induction and cesarean rates, would raise healthcare costs due to frequent examinations and investigations but not create any significant difference in maternal and neonatal outcomes. Our knowledge on this issue is based on limited number of randomized studies. In order to make precise recommendations for the management of such patients, we need further welldesigned randomized studies with larger population.

Conflicts of Interest: No conflicts declared.

\section{References}

1. Committee opinion no. 504: Screening and diagnosis of gestational diabetes mellitus. Obstet Gynecol 2011;118:751-3.

2. Gabbe SG, Niebyl JR, Galan HL, Jauniaux ERM, Landon MB, Simpson JL, Driscoll DA. Diabetes Mellitus Complicating Pregnancy. Obstetrics: Normal and Problem Pregnancies. 6th ed. Philadelphia: Saunders; 2012. p: 902-4.

3. Practice Bulletin No. 137. Gestational diabetes mellitus. Obstet Gynecol 2013;122(2 Pt 1):406-16.

4. Han S, Crowther CA, Middleton P. Interventions for pregnant women with hyperglycaemia not meeting gestational diabetes and type 2 diabetes diagnostic criteria. Cochrane Database Syst Rev 2012;1:CD009037.

5. Mulla WR, Henry TQ, Homko CJ. Gestational diabetes screening after HAPO: has anything changed? Curr Diab Rep 2010;10:224-8.

6. Metzger BE, Lowe LP, Dyer AR, Trimble ER, Chaovarindr U, Coustan DR. Hyperglycemia and adverse pregnancy outcomes. N Engl J Med 2008;358:1991-2002.

7. Dodd JM, Crowther CA, Antoniou G, Baghurst P, Robinson JS. Screening for gestational diabetes: the effect of varying blood glucose definitions in the prediction of adverse maternal and infant health outcomes. Aust N Z J Obstet Gynaecol 2007;47:307-12.

8. Stamilio DM, Olsen T, Ratcliffe S, Sehdev HM, Macones GA. False-positive 1-hour glucose challenge test and adverse perinatal outcomes. Obstet Gynecol 2004;103:148-56.

9. Edelman D, Olsen MK. Diagnosis and classification of diabetes mellitus. Diabetes Care 2010;33(Suppl 1):S62-S9.

10. Yee LM, Cheng YW, Liddell J, Block-Kurbisch IB, Caughey AB. 50-Gram glucose challenge test: is it indicative of outcomes in women without gestational diabetes mellitus? J Matern Fetal Neonatal Med 2011;24:1102-6.

11. Gumus II, Turhan NO. Are patients with positive screening but negative diagnostic test for gestational diabetes under risk for adverse pregnancy outcome? J Obstet Gynaecol Res 2008;34:359-63.

12. Gezer A, Esen F, Mutlu H, Oztürk E, Ocak V. Prognosis of patients with positive screening but negative diagnostic test for gestational diabetes. Arch Gynecol Obstet 2002;266: 201-4.

13. Dudhbhai M, Lim L, Bombard A, Jullard K, Meenakshi B, Trachelenberg Y, et al. Characteristics of patients with abnormal glucose challenge test and normal oral glucose tolerance test results: comparison with normal and gestational diabetic patients. Am J Obstet Gynecol 2006;194:e42-5.

14. Wolf M, Sandler L, Munoz K, Hsu K, Ecker JL, Thadhani R. First trimester insulin resistance and subsequent preeclampsia: a prospective study. J Clin Endocrinol Metab 2002;87:1563-8.

15. Beigelman A, Wiznitzer A, Shoham-Vardi I, Vardi H, Holtcberg G, Mazor M. Premature delivery in diabetes: etiology and risk factors. Harefuah 2000;138:919-23. 
16. James DK, Steer P, Weiner C, Gonik B, Crowther C, Robson S, et al. Pregnancy and laboratory studies: a reference table of clinicians. Obstet Gynecol 2010;115:868.

17. Ju H, Rumbold AR, Willson KJ, Crowther CA. Borderline gestational diabetes mellitus and pregnancy outcomes. BMC Pregnancy Childbirth 2008;8:31.

18. Jastrow N, Roberge S, Gauthier RJ, Laroche L, Duperron L, Brassard N, et al. Effect of birth weight on adverse obstetric outcomes in vaginal birth after cesarean delivery. Obstet Gynecol 2010;115(2 Pt 1):338-43.

19. Figueroa D, London MB, Mele L, Spong CY, Ramin SM, Casey B, et al. Relationship between 1-hour glucose chal- lenge test results and perinatal outcomes. Obstet Gynecol 2013;121:1241-7.

20. Bonomo M, Cetin I, Pisoni MP, Faden D, Mion E, Taricco $\mathrm{E}$, et al. Flexible treatment of gestational diabetes modulated on ultrasound evaluation of intrauterine growth: a controlled randomized clinical trial. Diabetes Metab 2004;30:237-44.

21. Dabelea D, Snell-Bergeon JK, Hartsfield CL, Bischoff KJ, Hamman RF, McDuffie RS; Kaiser Permanente of Colorado GDM Screening Program. Increasing prevalence of gestational diabetes mellitus (GDM) over time and by birth cohort: Kaiser Permanente of Colorado GDM Screening Program. Diabetes Care 2005;28:579-84. 